\title{
Intake of antibiotics and fasting during the Holy month of Ramadan: a literature review
}

\author{
Yousef Ahmed Alomi*, (D) General \\ Administration of Pharmaceutical Care, \\ Ministry of Health, Riyadh, SAUDI ARABIA. \\ Mohammed Abdulaziz Altuwaijri, \\ ENT Consultant, King Saud Medical City, \\ Riyadh, SAUDI ARABIA. \\ Mohsen Huraybie Alshammari, Hail \\ Maternaty and Childern Hospital, Ministry \\ of Health, Hail, SAUDI ARABIA. \\ Nouf Hameed Al-Muallad, Ibn Sina Col- \\ lege Hospital, Jeddah, SAUDI ARABIA.

\section{Correspondence: \\ Yousef Ahmed Alomi, Bsc. Pharm, MSc. Clin Pharm, BCPS, BCNSP, DiBA, The Former General Manager of General Administration of Pharmaceutical Care, Former Head, Pharmacy R\&D Administra- tion, Ministry of Health, Riyadh-11543, SAUDI ARABIA}

Phone no: +966504417712 E-mail: yalomi@gmail.com
Received: 25-12-2018;

Accepted: 27-2-2019

Copyright: (c) the author(s),publisher and licensee Pharmacology, Toxicology and Biomedical Reports. This is an open-access article distributed under the terms of the Creative Commons Attribution NonCommercial License, which permits unrestricted non-commercial use, distribution, and reproduction in any medium, provided the original work is properly cited.

This is an open access article distributed under the terms of the Creative Commons Attribution-NonCommercial-ShareAlike 4.0 License

Access this article online

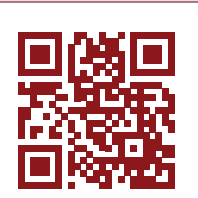

www.ptbreports.org

DOI:

10.5530/PTB.2019.5.11

\begin{abstract}
Objectives: To review the intake of antibiotics and fasting during the holy month of Ramadan. Methods: In this study, we performed an extensive search of 50 databases following the Saudi Digital Library search engine. We included meta-analysis, randomized controlled studies and observational studies published in English language with human study only for update May 2017. The search terms included Ramadan, fasting, medication, therapy, type of disease and medication based on therapeutic class. The list of antibiotic medication and switch from regular days to Ramadan days based on literature search revealed comparative safety studies, efficacy studies and cost of type of medication for each disease studies and national or international evidence-based guidelines of switching short half-life to long halflife. All parenteral dosage form of medication were excluded from study. All medications should be listed in the Ministry of Health drug formulary. Results: A total of 710 studies were obtained after an extensive search with specific terms. Of those, 104 studies were duplicate studies and 606 were considered for further evaluation. After evaluation, we obtained 30 studies which discussed about the antibiotics and Ramadan. Of these 30 studies, only 2 studies were found to be appropriate for further revision. Among the two, one study was an observational study regarding the pattern of prescribing antibiotics during the holy month of Ramadan. The second study was about the systemic review on the safety of fasting and several infectious diseases. The suggested draft of list of antibiotic switch from regular days to the holy Ramadan days was explored in this review. Conclusion: The investigations about antibiotics intake during fasting not found. The studies of antibiotic during the holy month of Ramadan is required during legal registrations at all Muslim countries. Antibiotics switch therapy during fasting is highly recommended at all Muslim patients in the world.

Key words: Antibiotics, Fasting, Ramadan, Literature, Review.
\end{abstract}

\section{INTRODUCTION}

The General Administration of Pharmaceutical Care founded the National Stewardship of Antimicrobial Program in 2014 at the MOH hospitals in the Kingdom of Saudi Arabia. ${ }^{1,2}$ The project was established through the pharmacy strategic planning task force committee. The program consists of antibiotic administration guidelines, elements of antibiotics committee and all related regulations of the antimicrobial stewardship program according to the American Society of Infectious Diseases. The antibiotic guidelines consisted of disease management and names of all available medications in the $\mathrm{MOH}$ drug formulary, the dosing frequency and time of administration. These guidelines are applicable during all months of the year. However, during the holy month Ramadan, it changes. In this month, all Muslims should perforce fast. The fast starts from sunrise and followed until sunsets. During this period, the patient should stop taking any medications. One systematic review discussed the effect of fasting in some infectious diseases. ${ }^{3}$ All the infectious diseases need the administration of antibiotics for disease management. The review, however, did not mention how to administer the medications during the holy month of Ramadan. To the best of our knowledge, there is no publication regarding the antibiotics switch from regular to Ramadan days in the KSA, Gulf and Middle Eastern countries. Therefore, in this study, we aimed to explore the intake of antibiotics and the time administration during the Ramadan fasting.

\section{METHODS}

In this study, we performed an extensive search on 50 databases included in the SDL search engine: Wiley Online Library, Web of Science, Springer Link, Taylor and Francis, Social Science Journal accessed via ProQuest, Science journal accessed via ProQuest, Scopus, SciFinder, Science Direct, Sage Journal, Royal Society of Medicine, Royal Society of Chemistry, Psychology Journals accessed via ProQuest, Pharmaceutical News Index accessed via ProQuest, Patient Education accessed via MD Consult, Drug accessed via MD Consult, Oxford Journals accessed via Oxford University Press, Ovid Journals, Nursing and Allied Health Sources accessed via ProQuest, Nature Publisher Group, Medline Index accessed via ProQuest, Medline Complete accessed via EBSCO, Medical Evidence Matter accessed via ProQuest, IGI InfoSci Journals, Health Management accessed via ProQuest, Health and Medical complete accessed via ProQuest, Global Health Database-CABI, Family Health accessed via ProQuest, Eric accessed via ProQuest and EBSCO, Emerald, DynaMed via EBSCO, Directory of Open Access Journal (DOAJ), Current Content accessed via Web of Knowledge, Dentistry and Oral Science accessed via EBSCO, Clinical Key- 
Nursing, Clinical Key-Physician, CINAHL accessed via EBSCO, Central accessed via ProQuest, CBCA accessed via ProQuest, Canadian Science Publishing. Cambridge Journals accessed via Cambridge University, Britannica Academic, BMJ Journals, BMJ Clinical Evidence accessed via BMJ Best Practice, BMJ Best Practice, Biology Journals accessed via ProQuest, ACM Digital Library, Academic Search Ultimate accessed via EBSCO, Cochrane Library PubMed. In addition to Google Scholar searched without SDL searching engine. We included meta-analysis, randomized controlled studies and observational studies published in English language and in May 2017. The search terms included Ramadan, fasting, medication, therapy, type of disease and medication based on therapeutic class. The medication list and switch from regular to Ramadan days based on literature search revealed comparative safety studies, efficacy studies and cost of type of medication for each disease studies and national or international evidence based guidelines of switching short half-life to long half-life.-6 The antibiotic medication list included drug name and general dosing and frequency of administration during regular and Ramadan days. All settings of patient care services such as inpatient, ambulatory care, or community services with oral medication were included. All parenteral medications were excluded from analysis. All medications should be included in the $\mathrm{MOH}$ drug formulary. The location of studies must include Saudi Arabia, Gulf, or Middle Eastern countries and if such data was not found, then other countries were included. If studies evidence not existed; the suggested came from author's experiences.

\section{RESULTS}

After an extensive search, a total of 710 studies were short-listed. Of these, 104 were found to be duplicate studies and 606 were included for further evaluation. Of the 606 studies, 92 studies discussed about medications related to diabetes mellitus and Ramadan, 27 studies discussed about the psychiatry and Ramadan, 27 studies investigated gastrointestinal diseases and Ramadan, 30 studies discussed about the intake of antibiotics and Ramadan, 30 studies discussed about the cardiovascular diseases and Ramadan, 15 studies discussed about medicines for asth- ma, rheumatoid arthritis and Ramadan and 402 studies discussed about other diseases and Ramadan. Of those 30 studies, only 2 were found to be appropriate for further analysis (Table 1). One of them was an observational study regarding pattern of prescribing antibiotics during Ramadan. The authors did not discuss the appropriate system of antibiotics that can be used alternatively during Ramadan. Besides, the study had a small number of patients and short period of duration. While the review study discussed about the fasting in case of several diseases such as hepatitis, infection in diabetes milieus, diarrheal diseases, appendicitis, urinary tract infection, eye infections. Regarding the medications, the anti-helminthic found Mebendazole, albendazole and pyrantel not affected by fasting. The suggested draft of antibiotics list switching from regular days to the holy Ramadan days (Table 2).

\section{DISCUSSION}

The General Administration of Pharmaceutical Care setup the strategic planning for antibiotics stewardship program at the $\mathrm{MOH} \cdot{ }^{1,7}$ This program includes key performance indicators and a self-assessment tool to monitor the outcome of the program. ${ }^{1}$ The program should be monitored throughout the year including the month of Ramadan. In previous studies, antibiotics showed most of the prescribing pattern and most of the Muslim patients wished not to break their fast during infectious diseases and to take treating antibiotics. ${ }^{8}$ Randomized controlled studies on the topic of switching antibiotics are scarce. Breakfasting with multiple doses to antibiotics given few doses and less frequency administration or single daily during fasting the holy month of Ramadan. The authors recommend a list of antibiotics that are appropriate to be taken during Ramadan without breaking the fast. The drug list based on microbial coverage with normal renal and hepatic functions. The list is very useful for the healthcare provider while prescribing the antibiotics during Ramadan. All healthcare providers should refer to other references to check about the approved indication and appropriate dosing for that indication. Further studies are highly recommended to validate the switch of antibiotics from regular days to Ramadan days.

\begin{tabular}{|c|c|c|c|c|c|c|c|c|}
\hline 운 & $\frac{\grave{o}}{\frac{1}{7}}$ & 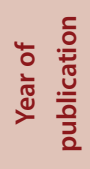 & 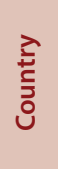 & 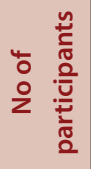 & 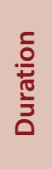 & $\begin{array}{l}\frac{c}{0} \\
\text { y } \\
0 \\
\text { ते } \\
\text { ஸे }\end{array}$ & हैँ & 華 \\
\hline 1 & $\begin{array}{l}\text { Mikhael } \\
\text { EM, Jasim } \\
\quad \mathrm{AL}^{8}\end{array}$ & 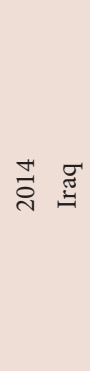 & & 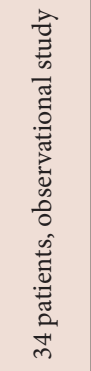 & $\begin{array}{l}\text { 密 } \\
\text { O }\end{array}$ & 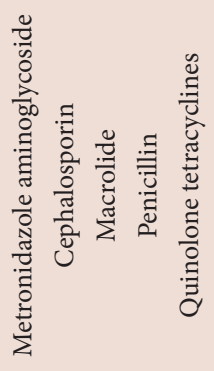 & $\begin{array}{l}\text { Metronidazole and cephalosporin were the most common types } \\
\text { of antibiotics that were prescribed for patients during Ramadan. } \\
\text { patients, even if they had been compliant with taking the drug } \\
\text { twice } \\
\text { daily just prior to and just after the fast, since this way of taking } \\
\text { the medication is not sufficient to ensure } 12 \text {-h intervals and is } \\
\text { thus best to be avoided to prevent the provoking of bacterial } \\
\text { resistance and treatment failure for fasting patients in Iraq } \\
\text { during Ramadan }\end{array}$ & $\begin{array}{l}\text { Small simple } \\
\text { size, Short } \\
\text { duration of the } \\
\text { study. }\end{array}$ \\
\hline 2 & $\begin{array}{l}\text { Bragazzi } \\
\text { NL et a. }{ }^{3}\end{array}$ & $\stackrel{\ln }{\stackrel{n}{1}}$ & 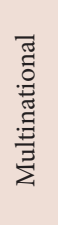 & 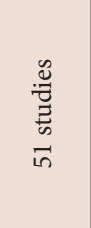 & $\begin{array}{l}\stackrel{n}{2} \\
\stackrel{\sim}{+} \\
\stackrel{\leftrightarrow}{2}\end{array}$ & 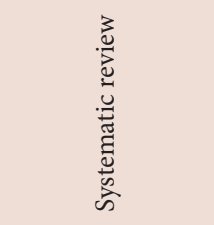 & $\begin{array}{l}\text { The disease covered was infectious in Diabetes mellitus, } \\
\text { Hepatitis, Diarrheal disease, HIV, Anti-helminthic therapy, Ulcer } \\
\text { disease, Appendicitis, Urinary tract infectious diseases, Eye } \\
\text { infectious diseases and Other infectious diseases }\end{array}$ & $\begin{array}{l}\text { The study about } \\
\text { demand of } \\
\text { Knowable and } \\
\text { education about } \\
\text { medication } \\
\text { during Ramadan }\end{array}$ \\
\hline
\end{tabular}


Alomi, et al:: Antibiotics and Fasting During the Holy Month of Ramadan

\begin{tabular}{|c|c|c|c|c|c|c|c|}
\hline \multirow[t]{2}{*}{ No } & \multicolumn{3}{|c|}{ Drug therapy during Regular days ${ }^{9}$} & \multicolumn{3}{|c|}{ Drug therapy during Holy Ramadan } & \multirow[t]{2}{*}{ Registration $^{10,11}$} \\
\hline & Regular Days & Doses/Day & $\begin{array}{c}\text { Frequency } \\
\text { Per day }\end{array}$ & Regular Days & Doses/Day & $\begin{array}{c}\text { Frequency } \\
\text { Per day }\end{array}$ & \\
\hline 1 & Amoxicillin & $250-500 \mathrm{mg}$ & 3 times/day & Cotrimoxazole & 490- $960 \mathrm{mg}$ & 2 times/day & RSFDA, MOHDF \\
\hline 2 & Cefacolr & $250-500 \mathrm{mg}$ & 3 times & Cefuroxim axitel & $250-500 \mathrm{mg}$ & 2 times & RSFDA, MOHDF \\
\hline 3 & Celeoxib & $200 \mathrm{mg}$ & 2 times & Celeoxib & $200 \mathrm{mg}$ & 2 times & RSFDA \\
\hline 4 & Cephalexin & $250-500 \mathrm{mg}$ & 4 times & Cefadroxil & $500-1000 \mathrm{mg}$ & 2 times & RSFDA, MOHDF \\
\hline 5 & Ciprofloxacin & $250-750 \mathrm{mg}$ & 2 times & Ciprofloxacin & $250-750 \mathrm{mg}$ & 2 times & RSFDA \\
\hline 6 & Cloxacillin & $250-500 \mathrm{mg}$ & 4 times & Cefadroxil & $500-1000 \mathrm{mg}$ & 2 times & RSFDA, MOHDF \\
\hline 7 & Cotrimoxazole & 490- $960 \mathrm{mg}$ & 2 times/day & Cotrimoxazole & $490-960 \mathrm{mg}$ & 2 times/day & RSFDA, MOHDF \\
\hline 8 & Doxycyline & $100-200 \mathrm{mg}$ & $\begin{array}{l}\text { Divided in 1-2 } \\
\text { doses }\end{array}$ & Doxycyline & $100-200 \mathrm{mg}$ & $\begin{array}{l}\text { Divided in 1-2 } \\
\text { doses }\end{array}$ & RSFDA, MOHDF \\
\hline 9 & Emtricitabine/tenofovir DF & $600 / 300 \mathrm{mg}$ & In 1 dose & Emtricitabine/tenofovir DF & $600 / 300 \mathrm{mg}$ & In 1 dose & RSFDA, MOHDF \\
\hline 10 & Erythromycin & $250-500 \mathrm{mg}$ & 4 times & $\begin{array}{l}\text { Clarithromycin } \\
\text { Azithromycin }\end{array}$ & $\begin{array}{l}250-500 \mathrm{mg} \\
500-1000 \mathrm{mg}\end{array}$ & $\begin{array}{c}2 \text { times } \\
1 \text { time }\end{array}$ & RSFDA, MOHDF \\
\hline 11 & Efavirenz [EFV] & $600 \mathrm{mg}$ & In 1 dose & Efavirenz [EFV] & $600 \mathrm{mg}$ & In 1 dose & RSFDA \\
\hline 12 & Flucloxacillin & $250-500 \mathrm{mg}$ & 4 times & Cefadroxil & $500-1000 \mathrm{mg}$ & 2 times & RSFDA, MOHDF \\
\hline 13 & Fluconazole & $50-400 \mathrm{mg}$ & In 1 dose & Fluconazole & $50-400 \mathrm{mg}$ & In 1 dose & RSFDA, MOHDF \\
\hline 14 & Itraconazole & $400 \mathrm{mg}$ & $\begin{array}{c}\text { Divided in } 2 \\
\text { doses }\end{array}$ & Itraconazole & $400 \mathrm{mg}$ & $\begin{array}{c}\text { Divided in } 2 \\
\text { doses }\end{array}$ & RSFDA, MOHDF \\
\hline 15 & Ketoconazole & 200- $400 \mathrm{mg}$ & In 1 dose & Ketoconazole & 200- $400 \mathrm{mg}$ & In 1 dose & RSFDA, MOHDF \\
\hline 16 & Mebendazole & $100 \mathrm{mg}$ & 2 times & Mebendazole & $100 \mathrm{mg}$ & 2 times & RSFDA, MOHDF \\
\hline 17 & Minocycline & $50-100 \mathrm{mg}$ & 1-2 times & Minocycline & $50-100 \mathrm{mg}$ & 1-2 times & RSFDA, MOHDF \\
\hline 18 & Moxifloxacin & $400 \mathrm{mg}$ & In 1 dose & Moxifloxacin & $400 \mathrm{mg}$ & In 1 dose & RSFDA, MOHDF \\
\hline 19 & Nalidixic Acid & $500-1000 \mathrm{mg}$ & 4 times & Norfloxacin Ciprofloxacin & $\begin{array}{l}400-800 \mathrm{mg} \\
250-750 \mathrm{mg}\end{array}$ & $\begin{array}{l}2 \text { times } \\
2 \text { times }\end{array}$ & RSFDA, MOHDF \\
\hline 20 & Norfloxacin & $400 \mathrm{mg}$ & 2 times & Norfloxacin & $400 \mathrm{mg}$ & 2 times & RSFDA, MOHDF \\
\hline 21 & Ofloxacin & $400 \mathrm{mg}$ & 2 times & Ofloxacin & $400 \mathrm{mg}$ & 2 times & RSFDA, MOHDF \\
\hline 22 & Posaconazole & $400 \mathrm{mg}$ & 2 times & Posaconazole & $400 \mathrm{mg}$ & 2 times & RSFDA, MOHDF \\
\hline 23 & Simeprevir & $150 \mathrm{mg}$ & In 1 dose & Simeprevir & $150 \mathrm{mg}$ & In 1 dose & RSFDA, MOHDF \\
\hline 24 & Sofosbuvir & $400 \mathrm{mg}$ & In 1 dose & Sofosbuvir & $400 \mathrm{mg}$ & In 1 dose & RSFDA \\
\hline 25 & Ledipasvir + Sofosbuvir & $90+400 \mathrm{mg}$ & In 1 dose & Ledipasvir + Sofosbuvir & $90+400 \mathrm{mg}$ & In 1 dose & RSFDA, \\
\hline 26 & Sparfloxacin & $\begin{array}{c}400 \mathrm{mg} \\
\text { loading } \\
\text { then } 200 \mathrm{mg}\end{array}$ & In 1 dose & Sparfloxacin & $\begin{array}{l}400 \mathrm{mg} \\
\text { loading then } \\
200 \mathrm{mg}\end{array}$ & In 1 dose & RSFDA, MOHDF \\
\hline 27 & Terbinafine & $250 \mathrm{mg}$ & In 1 dose & Terbinafine & $250 \mathrm{mg}$ & In 1 dose & RSFDA, MOHDF \\
\hline 28 & Trovafloxacin & $200 \mathrm{mg}$ & In 1 dose & Trovafloxacin & $200 \mathrm{mg}$ & In 1 dose & RSFDA, \\
\hline 29 & Voriconazol & $400 \mathrm{mg}$ & $\begin{array}{c}\text { Divided in } 2 \\
\text { doses }\end{array}$ & Voriconazol & $400 \mathrm{mg}$ & $\begin{array}{c}\text { Divided in } 2 \\
\text { doses }\end{array}$ & RSFDA, MOHDF \\
\hline 30 & Linezolid & $600 \mathrm{mg}$ & Every 12 hours & Linezolid & $600 \mathrm{mg}$ & Every 12 hours & RSFDA, MOHDF \\
\hline 31 & Azithromycin & $\begin{array}{c}500 \mathrm{mg} \\
1 \mathrm{~g}\end{array}$ & $\begin{array}{l}\text { Once Daily } \\
\text { In } 1 \text { dose }\end{array}$ & Azithromycin & $\begin{array}{c}500 \mathrm{mg} \\
1 \mathrm{~g}\end{array}$ & $\begin{array}{l}\text { Once Daily } \\
\text { In } 1 \text { dose }\end{array}$ & RSFDA, MOHDF \\
\hline 32 & Isoniazid & $\begin{array}{c}300 \mathrm{mg} \\
15 \mathrm{mg} / \mathrm{kg}\end{array}$ & $\begin{array}{c}\text { Once Daily } \\
3 \text { times a week }\end{array}$ & Isoniazid & $\begin{array}{c}300 \mathrm{mg} \\
15 \mathrm{mg} / \mathrm{kg}\end{array}$ & $\begin{array}{c}\text { Once Daily } \\
3 \text { times a week }\end{array}$ & RSFDA, MOHDF \\
\hline 33 & Rifampicin & $\begin{array}{l}600-900 \mathrm{mg} \\
450-600 \mathrm{mg}\end{array}$ & $\begin{array}{c}3 \text { times a week, } \\
\text { Once Daily }\end{array}$ & Rifampicin & $\begin{array}{l}600-900 \mathrm{mg} \\
450-600 \mathrm{mg}\end{array}$ & $\begin{array}{c}3 \text { times a week } \\
\text { Once Daily }\end{array}$ & RSFDA, MOHDF \\
\hline 34 & Rifabutin & $150-600 \mathrm{mg}$ & Once Daily & Rifabutin & $150-600 \mathrm{mg}$ & Once Daily & RSFDA, MOHDF \\
\hline 35 & Moxifloxacin & $400 \mathrm{mg}$ & Once Daily & Moxifloxacin & $400 \mathrm{mg}$ & Once Daily & RSFDA, MOHDF \\
\hline 36 & Levofloxacin & $500 \mathrm{mg}$ & $\begin{array}{c}1-2 \text { times } \\
\text { a day }\end{array}$ & Levofloxacin & $500 \mathrm{mg}$ & $\begin{array}{c}1-2 \text { times } \\
\text { a day }\end{array}$ & RSFDA, MOHDF \\
\hline
\end{tabular}


Alomi, et al.: Antibiotics and Fasting During the Holy Month of Ramadan

\begin{tabular}{|c|c|c|c|c|c|c|c|}
\hline 37 & Primaquine Phosphate & $\begin{array}{c}15-30 \mathrm{mg} \\
45 \mathrm{mg}\end{array}$ & $\begin{array}{c}\text { Once Daily } \\
\text { Once Weekly }\end{array}$ & Primaquine Phosphate & $\begin{array}{c}15-30 \mathrm{mg} \\
45 \mathrm{mg}\end{array}$ & $\begin{array}{c}\text { Once Daily } \\
\text { Once Weekly }\end{array}$ & RSFDA, MOHDF \\
\hline 38 & Albendazole & $400 \mathrm{mg}$ & Twice Daily & Albendazole & $400 \mathrm{mg}$ & Twice Daily & RSFDA, MOHDF \\
\hline 39 & Pyrazinamide & $1.5-2 \mathrm{~g}$ & Once Daily & Pyrazinamide & $1.5-2 \mathrm{~g}$ & Once Daily & RSFDA, MOHDF \\
\hline 40 & Dapsone & $50-100 \mathrm{mg}$ & Once Daily & Dapsone & $50-100 \mathrm{mg}$ & Once Daily & RSFDA, MOHDF \\
\hline 41 & Vancomycin & $125 \mathrm{mg}$ & Every 6 hours & Fidaxomicin & $200 \mathrm{mg}$ & Every 12 hours & RSFDA, MOHDF \\
\hline 42 & Metronidazole & $400-500 \mathrm{mg}$ & $\begin{array}{c}2-3 \text { times/ } \\
\text { Day }\end{array}$ & Metronidazole & $400-500 \mathrm{mg}$ & 2 times/Day ${ }^{*}$ & RSFDA, MOHDF \\
\hline 43 & Ethambutol & $15 \mathrm{mg} / \mathrm{kg}$ & Once Daily & Ethambutol & $15 \mathrm{mg} / \mathrm{kg}$ & Once Daily & RSFDA, MOHDF \\
\hline 44 & Tedizolid & $200 \mathrm{mg}$ & Once Daily & Tedizolid & $200 \mathrm{mg}$ & Once Daily & RSFDA, MOHDF \\
\hline 45 & Nitrofurantoin & $100 \mathrm{mg}$ & 2 times/Day & Nitrofurantoin & $100 \mathrm{mg}$ & 2 times/Day & RSFDA, MOHDF \\
\hline 46 & Itraconazole & $50-200 \mathrm{mg}$ & $\begin{array}{c}\text { Once - Twice } \\
\text { Daily }\end{array}$ & Itraconazole & $50-200 \mathrm{mg}$ & $\begin{array}{l}\text { Once - Twice } \\
\text { Daily }\end{array}$ & RSFDA, MOHDF \\
\hline 47 & Griseofulvin & $500 \mathrm{mg}-1 \mathrm{~g}$ & Once Daily & Griseofulvin & $500 \mathrm{mg}-1 \mathrm{~g}$ & Once Daily & RSFDA, MOHDF \\
\hline 48 & Aciclovir & $400 \mathrm{mg}$ & Twice Daily & Aciclovir & $400 \mathrm{mg}$ & Twice Daily & RSFDA, MOHDF \\
\hline 49 & Valganciclovir & $900 \mathrm{mg}$ & $\begin{array}{c}\text { Once - Twice } \\
\text { Daily }\end{array}$ & Valganciclovir & $900 \mathrm{mg}$ & $\begin{array}{c}\text { Once - Twice } \\
\text { Daily }\end{array}$ & RSFDA, MOHDF \\
\hline 50 & Zidovudine & $250-300 \mathrm{mg}$ & Twice Daily & Zidovudine & $250-300 \mathrm{mg}$ & Twice Daily & RSFDA, MOHDF \\
\hline 51 & Clarithromycin & $250-500 \mathrm{mg}$ & $\begin{array}{c}\text { Once - Twice } \\
\text { Daily }\end{array}$ & Clarithromycin & $250-500 \mathrm{mg}$ & $\begin{array}{l}\text { Once - Twice } \\
\text { Daily }\end{array}$ & RSFDA, MOHDF \\
\hline 52 & \multicolumn{7}{|c|}{ RSFDA: The Drug had been registered in Saudi Food and Drug Authority, MOHDF: The Drug is Ministry of Health Drug Formulary. } \\
\hline
\end{tabular}

\section{CONCLUSION}

The studies antibiotics intake while fasting the holy month of Ramadan has not existed. The implementation of some antibiotic switch from regular to fasting days is preferable in practice. Future investigation about antibiotics in Ramadan is highly recommended at all Muslim patients in the world.

\section{ACKNOWLEDGEMENT}

None.

\section{CONFLICT OF INTEREST}

The authors declare that there are no conflicts of interest.

\section{ABBREVIATIONS}

MOH: Ministry of Health; KSA: Kingdom of Saudi Arabia; USA: United State of America; RPC: Ramadan Pharmaceutical Care; SDL: Saudi Digital Library.

\section{ORCID ID}

Yousef Ahmed Alomi (iD https://orcid.org/0000-0003-1381-628X

\section{REFERENCES}

1. Alomi YA. National Antimicrobial Stewardship Program in Saudi Arabia; Initiative and the Future. Open Access J Surg. 2017;4(5):1-7.

2. Alomi YA. National Pharmacy Practice Programs at Ministry of
Health in Saudi Arabia. J Pharm Pharm Scien. 2015;1(2):17-18.

3. Bragazzi NL, Briki W, Khabbache H, Rammouz I, Mnadla S, Demaj T, et al. Ramadan fasting and infectious diseases: A systematic review. J Infect Dev Ctries. 2015;9(11):1186-1194.

4. Aadil N, Houti IE, Moussamih S. Drug intake during Ramadan. Br Med J. 2004;329(7469):778-782.

5. Begum Y. GP guide to managing patients who wish to fast during Ramadan. Prescriber. 2015;22(13-14):14-21.

6. Alomi YA. Update 2013- Drug Therapy during Holy Month of Ramadan. 2013. Minitery of Health. Saudi Aarbia.

7. Alomi YA, Alghamdi SJ, Alattyh RA, Elshenawy RA. The Evaluation of Pharmacy Strategic Plan in Past 2013-2016 and Forecasting of New Vision 2030 at Ministry of Health in Saudi Arabia. J Pharm Pract Community Med. 2018 ;4(2):93-101.

8. Mikhael EM, Jasim AL. Antibiotic-prescribing patterns for Iraqi patients during Ramadan. Patient Prefer Adherence. 2014;8:1647-51.

9. Royal Pharmaceutical Society. British National Formulary 76. Ah-See KW, et al, editors. British National Formulary. BMJ Group; 2019. 1-1653.

10. Saudi Food and Drug Authority. List of human medicine and herbal health [cited 2019 Jun 17]. Available from: https://www. sfda.gov.sa/en/drug/resources/Pages/DrugsUnderRegistrations.aspx

11. Ministry of Health. Ministry of Health Formulary. Health Ministry of Health. 2012. 